\title{
透過性遮光板をもつ凹閉面室内空間の照度分布と 光束保存性のモンテカルロシミュレーション
}

\author{
正 員 長 田 正義（徳島大）
}

\begin{abstract}
Monte Carlo Simulation of Illuminance Distribution and Conservation of Luminous Flux in Cubic Room with Transparent Visual Obstructions Masayoshi Nagata, Member (Technical College of the University of Tokushima)
\end{abstract}

キーワード : 透過性遮光板, 1,600 面素, 照度分布, 変動係数, モンテカルロシミュレーション

実際の室内空間に設置されている衝立やひさしなど 遮光板には透過性のものが存在している。図 1に示す ように，1辺が $1 \mathrm{~m}$ の立方体室内空間に床面と直交し て透過性の衝立 2 枚, 一方, 床面と平行に透過性ひさ し1枚を設置し.，全光束 $100 \mathrm{~lm}$ の半球面状配光光源 を天井面中心点に取付け, 室内各面の照度分布をモン テカルロシミュレーション (MCS) により求めた(1)。 室内各面は図 1 のように番号を付け, $40 \times 40=1,600$ 面素に分割した。室内面照度分布に及ほす衝立やひさ しなど遮光板の影響をできるだけ視覚的に明確なもの とするために，今回，照度分布を三次元的に表現し た。すなっち, 図 2 と図 3 の縦横軸に室内面各辺を 40 等分した分割番号を，一方，この平面と直交する 軸上に各面素の照度值を示した。

室内面が反射率 $\rho$, 透過率て扔よび吸収率 $\alpha$ をも

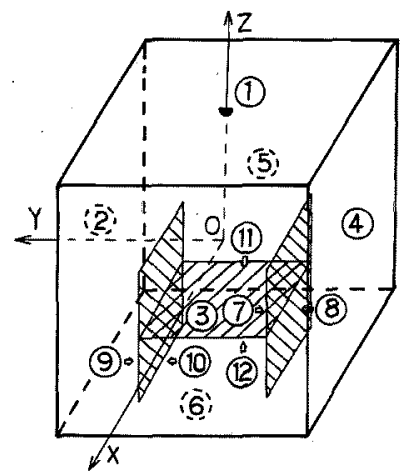

図 1 凹閉面室内空間の概略図

Fig. 1. Schematic diagram of a cubic room with transparent visual obstructions.
つとき，入射光子束が室内面でいずれの現象を生起す るかの判定は，一様乱数 $r$ にり次のように決定し た。すなわち， $0 \leqq r<\tau$ のとき入射光子束は透過し， $\tau \leqq r<(\tau+\rho)$ のを反射, また $(\tau+\rho) \leqq r \leqq 1 の と$ きには入射光子束が吸収されるとした ${ }^{(2)}$ 。なお，光源 からの放射光子束数を 1,000 万とした。

床面6の照度分布を図2(a)，(b)に示す。(a)図

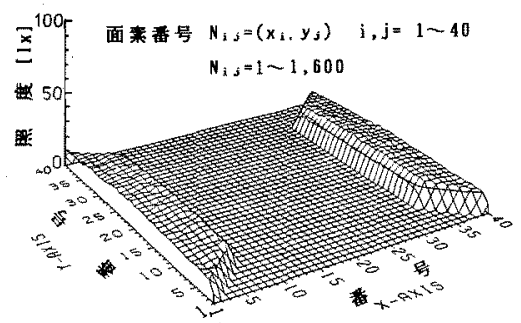

(a) $\rho_{1,2}=\tau_{1,2}=0.0$

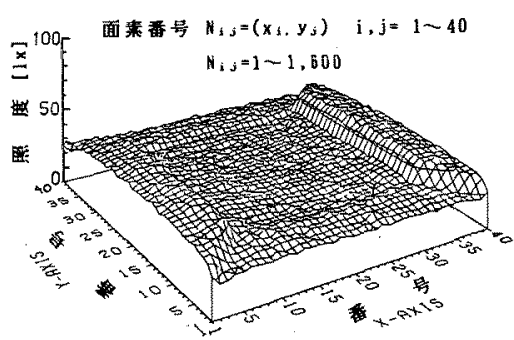

(b) $\rho_{1}=0.6, \alpha_{2}=0.4$ $\rho_{2}=0.6, \alpha_{2}=0.4, \tau_{2}=0.2$

図 2 床面(6)の照度分布

Fig. 2. Illuminance distribution on the floor surface (6). 


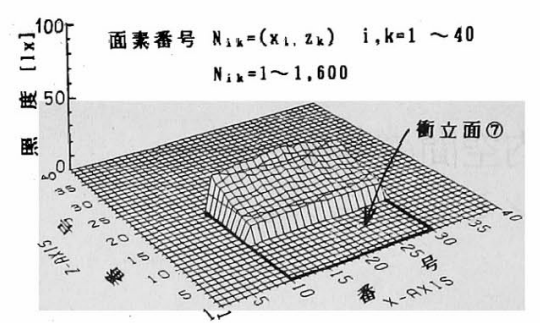

(a) $\rho_{1,2}=\tau_{1,2}=0.0$

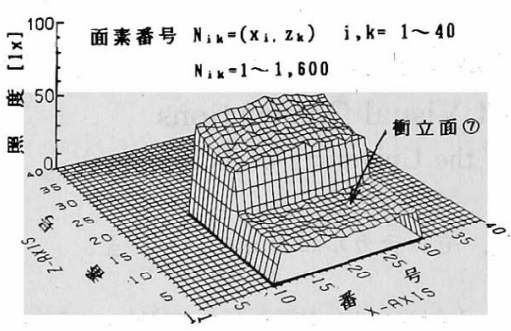

(b) $\rho_{1}=0.6, \alpha_{2}=0.4$ $\rho_{2}=0.6, \alpha_{2}=0.4, \tau_{2}=0.2$

図 3 衝立面(7)の照度分布

Fig. 3. Illuminance distribution on the partition surface (7).

は遮光板各面と室内 6 面すべての反射率と透過率が 零, すなわち, 各面が Black Wall を構成している事 例である。直射照度のみが存在して, 遮光板による影 の領域が大半を占めている。(b)図は室内面(1)（6)の 反射率 $\rho_{1}=0.6$, 吸収率 $\alpha_{1}=0.4$, 透過率 $\tau_{1}=0$, 一 方, 遮光板の $\rho_{2}=0.6, \alpha_{2}=0.2, \tau_{2}=0.2$ の場合の照度 分布を示す。室内 6 面の反射率と遮光板の透過率およ び反射率が増加した結果；（a 図において遮光板の影 で被われ照度が零であった領域にも，拡散照度が現れ ている。図 2(a)，（b)に扔ける照度分布の変動係数 （=標準偏差/平均值 $\times 100 \%$ ） 隹（a）図の $157 \%$ から (b) 図の $23 \%$ ，また衝立面(7)の照度分布を示す図 3(a)，（b )では，同様に $109 \%$ から $55 \%$ へと両者と も低下し, 照度分布の一様性は反射率と透過率の增加 により増大することがわかる。ここで，室内空間に存 在する遮光板の透過率 $\tau_{2}$ が, 仮に 1.0 とすれば理論 的には遮光板が存在しない中空室内空間と同一であ る。そこで，中空室内空間と仮定したものと $\tau_{2}=1.0$
とした二つの事例について室内 6 面の照度分布を MCSで求めた。その結果, 入射光子束数と照度分 布の変動係数に関する両者の相対誤差は, いずれも $0.1 \%$ 以下で比較的よく一致することが確かめら れた ${ }^{(2)}$ 。

次に，本室内空間における光束保存性を検討する。 エネルギー不滅則から光源より放射された光子束数は 室内空間で吸収された光子束数に等しい。一例として 図 2(b)の事例, $\rho_{1}=0.6, \alpha_{1}=0.4$, そして $\rho_{2}=0.6$, $\alpha_{2}=0.2, \tau_{2}=0.2$ の場合を検討する。室内面(1)〜(6) 人 の総入射光子束数は $23,016,253$ であり，そのうち吸収 光子束数は $23,016,253 \times(1-0.6-0)=9,206,501$ であ る。一方， 3 枚の遮光板両側面への総入射光子束数怯 $3,964,155$ で, 吸収光子束数は $3,964,155 \times(1-0.6-0$. 2) $=792,831$ となる。従って，本室内空間における䌊 吸収光子束数は両者の和で，9,999,332 となる。それ 由元，光源からの放射光子束数， $1 \times 10^{7}$ と総吸収光 子束数との相対誤差は約 $0.007 \%$ となり, 両者は 涩，一致していることがわかる。

(平成 2 年 2 月 20 日受付)

\section{文献}

（1）興田：「複数の遮光板をもつ凹閉面室内空間の照度分布 と光 束保存性のモンテカルロシミュレーション」, 電学論 $\mathrm{A}$, 110,101 (平 2-2)

（2）長田，他：「透過性遮光板をもつ凹閉面室内空間の照度分布 と光束保存性の MCS (II) 」, 平元電気関係学会四国支部連 大, $11-9$, p. 343

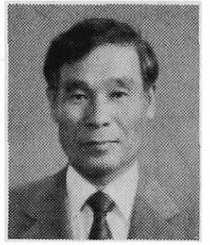

\section{長 田 正 義（正員）}

昭和 11 年 9 月 5 日生。 41 年 3 月 徳島大学大学院工学研究科修了。41 年 3 月同大学工学部助手, 43 年 11 月同工業短期大学部講師, 46 年 11 月同助教授， 54 年 4 月同教授，現在に至る。工学博 士。主として，高温ガス中の放電現象，アーク㵂断現 象およびモンテカルロシミュレーションによる室内照 明設計に関する研究に従事。照明学会, 放電研究グル ープ, IEEE，火災学会会員。 